\title{
Why 16 Million Bonded Labourers Remain Invisible: What Althusser Has to Say
}

\author{
Kevin Brinkmann \\ Author of The Global Leader ${ }^{\mathrm{TM}}$ at kevinbrinkmann.com, New Delhi, India \\ Email: kevin_brinkmann@yahoo.com
}

How to cite this paper: Brinkmann, $\mathrm{K}$. (2018). Why 16 Million Bonded Labourers Remain Invisible: What Althusser Has to Say. Advances in Applied Sociology, 8, 49-55. https://doi.org/10.4236/aasoci.2018.81003

Received: September 15, 2017

Accepted: January 15, 2018

Published: January 18, 2018

Copyright $\odot 2018$ by author and Scientific Research Publishing Inc. This work is licensed under the Creative Commons Attribution-NonCommercial International License (CC BY-NC 4.0). http://creativecommons.org/licenses/by-nc/4.0/ (c) (i) \& Open Access

\begin{abstract}
Seventy years after the UN Declaration of Human Rights, sixteen million bonded labours remain largely unnoticed in South Asia. Why? The most fundamental reason may not lie within economics or politics but in ideology.
\end{abstract}

\section{Keywords}

Ideology, Hegemony, Slavery, Criminal Sociology, South Asia

\section{Introduction}

It is unsettling that $1.1 \%$ of South Asia's population is still in bonded labour, and yet it remains largely invisible. Bonded labour is commonly thought to be a thing of the past but is in fact on the rise, riding on the wave of transnational migration and globalization (Smolin, 1999: 383; Derks, 2010: 839; Kapadia, 2008: 446). Of all forms of slavery, bonded labour is the most common form of slavery today (Belser, et al., 2005: 1; Herzfeld, 2010: 50). Many are pushed into bonded labour by taking a loan in order to pay emergency health expenses (Oosterhoff, et al., 2017: 5), after which they remain trapped in bonded labour for an average of 6.5 years (Kara, 2012: 421).

In 2005, the International Labour Organization (ILO) called bonded labour "one of the most hidden problems of our time" (p. 17). This is remarkable considering that there are approximately 18 to 20.5 million bonded labourers in the world today, and over $80 \%$ of those are in South Asia (Kara, 2012: 319). This paper will explore the question: how have 16 million bonded labourers in South Asia gone largely unnoticed?

As the majority of these 16 million are in India, India will serve as a case study in this analysis to understand this wider problem (Global Slavery Index, 2016). Bonded labour will be defined as per the Indian Constitution as a form of forced 
labour, where a person, because of a debt or other obligations (often a cash advance) loses any one or more of the following: 1) freedom of movement, 2) free of employment, 3) the right to be paid minimum wages, 4) the right to sell goods at market value. From a theory perspective, bonded labour will be viewed through the lens of human rights, as defined by UN Declaration of Human Rights, and analyzed through the theoretical lens of ideology, as defined by Louis Althusser and Antonio Gramsci.

The research method is a case study with literature review as theoretical proof. Building on a synthesis of empirical studies from the past twenty years, this paper argues that there are at least four practical reasons and one ideological reason why 16 million bonded labourers remain (largely) invisible: 1) It is not recognized individually. 2) It is not studied academically. 3) It is not admitted politically. 4) It is not enforced legally. But the deepest and most pervasive reason is that 5) it is expected by society. In South Asia, bonded labour has not only become normal; it has become a part of a cultural inequity mindset. After a thorough country study, Srivastava (2005) concluded, "It is apparent from the evidence presented ... that bonded and forced labour in India, whether traditional or modern, thrives on a bedrock of social hierarchy and discrimination" (Srivastava, 2005: 9). We will return to this point after addressing the four practical reasons bonded labour has gone unnoticed.

\section{Discussion and Analysis}

\subsection{Not Recognised}

At an individual level, often, bonded labour is often simply not recognized. This may be innocent enough, due to two reasons: 1) The myriad of names "bonded labour" assumes; 2) the lack of a popular, understood definition of what bonded labour actually is. It is not surprising that bonded labour is not called bonded labour or debt labour or slavery by the employers, but it is surprising that there are so many names for bonded labour. The names correspond with the myriad of industries that bonded labour finds itself embedded into-forced marriage in return for money, debt-bondage in return for labour, child labour in return for [a] promised remuneration (Campbell \& Stanziani, 2013: 5; Upadhyaya, 2004: 118). In South Asia, bonded labour persists in almost every economic sector: urban, rural, service, production, construction (Upadhyaya, 2004: 119). In ancient Indian mythology, the divine sage Narada lists fifteen different names for fifteen different types of slavery, four of which today would be called bonded labour (Kara, 2012: 3766). More recently, the Bonded Labour System Act (BLA) of 1976 lists thirty different names for bonded labour used throughout India. None are called slavery, which obscures the reality to both the observer and the oppressed.

Additionally, bonded labour is not recognised due to the lack of a popularly understood definition of what constitutes bonded labour. Dottridge (2017) has argued that anti-slavery and anti-trafficking initiatives will "not be effective un- 
less greater clarity is achieved about the forms of exploitation that are themselves considered to be crimes" (p. 40). For example, in Punjab, authorities had "a poor understanding about legal definition of bonded labour" and therefore applied "their own interpretations" to "deny the existence of bonded labourers in their districts" (Upadhyaya, 2008: 19). While the BLA spells out the conditions which qualify as bonded labour, it is written for legal clarity and not for popular understanding. If this is true even among legal authorities, how much more for the common person?

Moreover, the word "bonded" tends to obscure the reality of bonded labour. It is not by chains and high walls that labourers are chained, but by debt, oppression, and fear (Sahu, 2012). Without widespread conceptual clarity as to what characteristics define bondage, it will continue to remain unrecognized. Thankfully, in the case of India, a more popular, comprehensible definition of bonded labour is being circulated through the national "Bandhua 1947" campaign, spearheaded by the NGO International Justice Mission.

\subsection{Not Studied}

Bonded labour is the most common form of slavery in India (and the world) today, and yet "there are few systematic analyses of the causes and correlates of bonded labour in India” (Srivastava, 2005: 9). Moreover, there are surprisingly few empirical studies, despite its 16 million person scope (Ambeth Selvi \& Madhava Soma Sundaram, 2008: 308; Chandra \& Jaishankar, 2017: 180). Why? Despite its difficulties, why has it merited so little research attention? Why, forty years after the implementation of the Bonded Labour Act, was the ILO still calling the Government of India to take up its research responsibility, noting that "until today no comprehensive survey [of bonded labour] existed" (Anti-Slavery, 2001: 5)? While there is not a single answer to this question, the fact of the matter goes a long way toward explaining how this form of slavery continues largely under the radar screen of most academics.

\subsection{Not Admitted}

Bonded labour has been outlawed since at least 1948, with the adoption of the United Nation's Declaration of Human Rights and Article 23 of the Indian Constitution. Perhaps, partly as a result, "for the first three decades after independence, the country's rulers refused even to acknowledge the phenomenon of debt-bonded labourers" (Shankar, 1996: 2215). The paper law obscured the reality. The dynamic continued.

In 1976 when the Bonded Labour Act brought the issue to light, a large number of labourers were released, but thereafter "most of the states duped themselves into believing that the problem was over, and that India did not have any more bonded labourers" (Lal, 2012). Again vision was mistaken for implementation, and "the government viewed the passing of the Bonded Labour System (Abolition) Act as synonymous with the freeing of all bonded labourers and 
cancelling of their debts" (Shankar, 1996: 2215).

\subsection{Not Enforced}

The fourth reason for bonded labour's invisibility is the most concerning. In 1997, Indian Supreme Court Chief Justice J.S. Verma appointed the National Human Rights Commission (NHRC) to oversee the eradication of bonded labour through its political machinery. The NHRC appointed two special rapporteurs to investigate the effectiveness of the district vigilance committees, and upon completion of their investigation, they came to a very sobering conclusion. More than $50 \%$ of the district had no vigilance committees and another $30 \%$ had become defunct (Lal, 2012). More concerning, the same special rapporteur said, "In my experience, I have never come across a case where the vigilance committee had identified a case of bonded labour" (Lal, 2012).

Even in cases where the law has been enforced, it has been mild and seasonal. If an employer is found guilty of bonded labour, he may be fined for as little as Rs. 50 (Nair, 2012). With so little to lose, it is not surprisingly that he would return to the same profitable business as before. In light of this pattern, the ILO recommends that punishment include confiscation of financial assetts to discourage perpetrators from returning to this lucrative labour (Belser, 2005: 1). As it is, it is no wonder that this sort of punishment does not make a dent or make the headlines. Bonded labour continues unnoticed.

Second, enforcement is seasonal. For example, while a great number of labourers were released after the BLA 1976, the same enforcement has slowed to a standstill in most states since the 1990s (Upadhyaya, 2008: 16-18). The enforcement comes when external pressure forces it, but it has never been sustained by an intrinsic will. Without will, any long-term change is unlikely.

Third, enforcement is not initiated. In many cases, the onus of responsibility to file a case against slaveholders falls into the laps of illiterate victims. They cannot navigate the legal maze of filing a legal petition or hiring a lawyer (Chandra \& Jaishankar, 2017: 175). In this case, enforcement requires more than laws and police enforcement, it requires micro-level entities to enable and empower victims of modern slavery (Palanichany, 2016: 11).

\subsection{The Most Fundamental Reason}

Bonded labour persists worldwide, but not every country has a vision to eliminate it. India does. The Preamble of the Constitution proclaims that India exists "to secure to all its citizens justice, liberty, equality, and fraternity." Moreover, India amended the Constitution with the Bonded Labour Act of 1976 to reinforce these goals of justice, liberty, equality, and fraternity.

So if the goal is clear, why does bonded labour persist? The thesis of this article is that it persists because it is unnoticed, and it is unnoticed for five reasons. The first four reasons are relatively practical and common sense. However, the fifth is the most complex and most significant. The most fundament reason why 
bonded labour remains largely unnoticed is that it is expected. That is to say it fits an assumption of inequity which may be called an "inequity mindset". While inequity is universal, an inequity mindset is not. An inequity mindset is the result of the process of hegemony, as described by Louis Althusser and Antonio Gramsci (Prakash, 2002: xi-xii). Typically, hegemony follows a three-stage process until some form of power-imbalance is accepted as normal. The three stages are the power stage, negotiation stage, and consent stage.

In the power stage, an inequity mindset is shaped by practices through the means of interpellation. Althusser (1971: 170, 165, 174) describes interpellation (his "central thesis") as the "material existence" of ideology, which "recruits" individuals and "transforms" them "into subjects". Thus, as bonded labourers are "recruited" into oppressive relationships, they are not only acting labourers but in some way have become "transformed" into subjects--namely, bonded labourers. Thus by the mere practice of bonded labour, an inequity mindset begins to form in the subconsciousness of both the ruling and the oppressed classes.

In the negotiation stage, an inequity mindset is shaped by ideology through the means of Ideological State Apparatuses (ISAs) informed by ruling intellectuals. Althusser describes ISAs as institutions of socialization, including religion, education, family, media etc. (p. 143). ISAs are distinct from repressive state apparatus such as the government or police in three ways: 1) they exist largely in the private sector; 2) they have a plurality of voices; and 3) they exercise influence not by violence but by ideology (pp. 144-145). Through ISA's work in the private sphere, power imbalances are negotiated for the political and economic sphere. In fact, Althusser goes so far as to say, "No [economic] production is possible which does not allow for the reproduction of the material conditions of production: the reproduction of the means of production" (p. 128), and "no class can hold State power over a long period without at the same time exercising its hegemony over and in the State Ideological Apparatuses" (p. 146). Therefore, if Althusser is correct, then bonded labour is not only an economic phenomenon, but it requires an inequity mindset to support it.

Srivastava (2005) corroborated this with his study of bonded labour: "It can be hypothesized that the low visibility of the issue of bondage is due precisely to the fact that its many victims have a low social ascription and fewer perceived rights" (p. 9; see also Kumar, 2006: 4281). In this case, the ruling classes are exercising an inequity mindset which supports the material conditions of productions-namely, cheap labour. Or, in the case of Choi-Fitzpatrick's (2017) interviews with contemporary slaveholders, he found that many of the perpetrators were not the face of pure evil many imagine them to be. Rather, they are surprisingly human, able to rationalize their slaveholding on the basis of paternal care for slaves who would have no economic options otherwise (p. 3).

Finally, in the third stage an inequity mindset solidifies not only in the mind of the ruling but also in the minds of the oppressed. This is what Gramsci called the "philosophy of common sense"-the end-product of hegemony. It is the "'philosophy of nonphilosophers', or in other words, the conception of the world 
which is uncritically absorbed by the various social and cultural environments" (p. 769). Bonded labourers are these nonphilosophers.

N. B. Kamble (1982: 134) in his landmark book on bonded labour in India describes this common sense: "Victims of this system even if provided an opportunity to liberate themselves, could not do so, because they were acclimatized". At this stage, an inequity mindset is fully formed, or acclimatized. The oppressed no longer need to be controlled by power or persuasion because they give their "'voluntary' consent" (Gramsci, 1971: 155; see also Breman, 1996: 210). For them, bonded labour is "normal" (Smolin, 1999: 383). The assumptions of the inequity mindset are now taken for granted and exist uncontested, making 16 million bonded labourers, too, expected and largely unnoticed (Gamson et al., 1992).

\section{Conclusion}

While many researchers have pointed to the economic and political forces perpetuating bonded labour, only few has tackled the cultural roots perpetuating bonded labour. As a result, bonded labour interventions tend to focus on the economic and political dimensions of the problem. This is good but insufficient. Without recognizing the cultural roots of bonded labour (i.e. its ideology), bonded labour is likely to continue unnoticed. Thankfully, this is not the end of the story. It is hoped this article will elucidate how inequity mindsets form and thus might be re-formed toward shared goals of justice, liberty, equality, and fraternity for all.

\section{References}

Althusser, L. (1971). Lenin and Philosophy and Other Essays (Translated from the French by Ben Brewster). New York: Monthly Review Press.

Ambeth Selvi, A., \& Madhava Soma Sundaram, P. (2008). No Law, Low-Enforcement Trap: A Glimpse of Victimization of Girls through Soft Trafficking. In P. Madhava Soma Sundaram, K. Jaishankar, \& S. Ramdass, Crime Victims and Justice: An Introduction to Restorative Principles (pp. 308-319). New Delhi: Serials Publications.

Belser, P. (2005). Forced Labour and Human Trafficking: Estimating the Profits. Geneva: International Labour Organization.

Belser, P., de Cock, M., \& Mehran, F. (2005). ILO Minimum Estimate of Forced Labour in the World. Geneva: International Labour Organization.

Breman, J. (1996). Footloose Labour: Working in India's Informal Economy. Cambridge: Cambridge University Press.

Campbell, G., \& Stanziani, A. (2013). Bonded Labour and Debt in the Indian Ocean World. London: Pickering \& Chatto.

Chandra, R. R., \& Jaishankar, K. (2017). Female Victims of Labor Exploitation Vis-à-vis Labor Courts in Southern Tamil Nadu, India: Therapeutic Jurisprudence Solutions for the Prevention of Secondary Victimization. In D. Halder, \& K. Jaishankar (Eds.), Therapeutic Jurisprendendence and Overcoming Violence against Women. Hershey (PA): IGI Global.

Choi-Fitzpatrick, A. (2017). What Slaveholders Think: How Contemporary Perpetrators 
Rationalize What They Do. New York: Columbia University.

Derks, A. (2010). Bonded Labour in Southeast Asia: Introduction. Asian Journal of Social Science, 38, 839-852.

Dottridge, M. (2017). Trafficked and Exploited: The Urgent Need for Coherence in International Law. In P. Kotiswaran (Ed.), Revisiting the Law and Governance of Trafficking, Forced Labor and Modern Slavery. Cambridge (UK): Cambridge University Press.

Gamson, W., Croteau, D., Hoynes, W., \& Sasson, T. (1992). Media Images and the Social Construction of Reality. Annual Review of Sociology, 18, 373-393.

Global Slavery Index (2016). https://www.globalslaveryindex.org/country/india/

Gramsci, A. (1971). Selections from the Prison Notebooks. New York: International Publishing Co.

International Labour Office (2005). A Global Alliance against Forced Labour. Geneva: International Labour Office.

Kamble, N. D. (1982). Bonded Labour in India. New Delhi: Uppal Publishing House.

Kapadia, K. (2008). The Profitability of Bonded Labour: The Gem-Cutting Industry in Rural South India. The Journal of Peasant Studies, 22, 446-483.

Kara, S. (2012). Bonded Labor: Tackling the System of Slavery in South Asia (Kindle Edition). New York, NY: Columbia University Press.

Kumar, A. (2006). Culture, Development and the Cultural Capital of Farce: The Musahar Community in Bihar. Economic and Political Weekly, October 7, 2006.

Lal, C. (2012). Speech at the Bandhua 1947 Campaign Launch, 31 October 2012. New Delhi: International Justice Mission.

Nair, P. M. (2012). Speech at the Bandhua 1947 Campaign Launch, 31 October 2012. New Delhi: International Justice Mission.

Oosterhoff, P., Burns, D., Bharadwaj, S., \& Nanda, R. B. (2017). Participatory Statistics to Measure Prevention in Bonded Labour Hotspots in Uttar Pradesh and Bihar: Findings of the Baseline Study. Brighton: Institute of Development Studies.

Palanichany, A. (2016). Child Rights, Poverty and Protection: An Indian Perspective. Journal on Rights of the Child, 1, 1-17.

Prakash, G. (2002) Bonded Histories: Genealogies of Labor Servitude in Colonial India. Cambridge: Cambridge University Press.

Sahu, M. (2012). Speech at the Bandhua 1947 Campaign Launch, 31 October 2012. New Delhi: International Justice Mission.

Shankar, K. (1996). Bonded Agricultural Labour in India of 1996: Case of Hallia Block in UP(pp. 2215-2217). Economic and Political Weekly, August 17, 1996.

Smolin, D. M. (1999). Conflict and Ideology in the International Campaign against Child Labour. Hofstra Labor and Employment Law Journal, 16, 383-451.

Srivastava, R. S. (2005). Bonded Labour in India: Its Incidence and Pattern. Geneva: International Labour Office.

Upadhyaya, K. (2004). Bonded Labour in South Asia: India, Nepal and Pakistan. In C. van den Anker (Ed.), The Political Economy of New Slavery (pp. 118-136). London: Palgrave Macmillan. https://doi.org/10.1057/9781403937865_8

Upadhyaya, K. (2008). Poverty, Discrimination, and Slavery: The Reality of Bonded Labour in India, Nepal, and Pakistan. London: Anti-Slavery International. 